DOI: https://doi.org/10.24127/ajpm.v8i1.1469

\title{
ANALISIS KEBERHASILAN AKADEMIK MAHASISWA PROGRAM STUDI PENDIDIKAN MATEMATIKA UNIVERSITAS MUHAMMADIYAH METRO
}

\author{
Nego Linuhung ${ }^{1}$, Nurain Suryadinata ${ }^{2}$ \\ ${ }^{1,2}$ Pendidikan Matematika, Universitas Muhammadiyah Metro \\ E-mail:nego_mtk@yahoo.co.id ${ }^{1)}$ \\ nurain.suryadinata@gmail.com ${ }^{2)}$
}

Received 18 June 2018; Received in revised form 20 September 2018; Accepted 16 October 2018

\begin{abstract}
The quality of a student can be demonstrated from academic success as reflected in the cumulative achievement index (GPA) achieved. This study aims to analyze the factors that influence the academic success of students of the Mathematics Education Study Program at Muhammadiyah Metro University, examine the significance of the overall and individual model parameters, and form a binary logistic model of student success. The subjects of this study were students in Mathematics Education at Muhammadiyah University of Metro. While the sample used is students of the 2-6 semester Mathematics Education of Muhammadiyah Metro University 2017/2018 Academic Year as many as 108 students. Based on the results of the study and discussion, the conclusions are: 1) Based on the variables that have been included in this study, the factors that most influence the academic success of students as indicated by GPA acquisition with the "With Praise" category are the major factors taken students while studying in high school (SMA) / equivalent; 2) The overall model parameters have a significant influence on the academic success of students and individually / partially the most significant influence is the departmental factor; 3) The regression model that is formed is $g(x)=-0,924-2,575($ Jurusan_1).
\end{abstract}

Keywords: Academic success; GPA; Intellectual and non-intellectual factors.

\section{PENDAHULUAN}

Kualitas seorang mahasiswa dapat dilihat dari prestasi yang dicapainya, potensi yang dimiliki, dan juga motivasi yang tinggi yang ada dalam dirinya, latar belakang keluarga, dukungan orang tua, lingkungan belajar, sarana dan prasarana yang tersedia dan motivasi serta minat untuk berprestasi. Menurut Daruyani, dkk. (2013: 185) keberhasilan mahasiswa dalam bidang akademik ditandai dengan prestasi akademik yang dicapai, ditunjukkan melalui indeks prestasi (IP) maupun indeks prestasi kumulatif (IPK). Dalam perkuliahan mahasiswa dituntut untuk berkompetisi dalam memperoleh prestasi akademik, yang dalam ini sebagai tolak ukurnya adalah indeks prestasi. Sejalan dengan pendapat tersebut Saleh (2014:110) mengungkapkan bahwa keberhasilan mahasiswa dalam bidang akademik ditandai dengan prestasi akademik yang dicapai, ditunjukkan melalui Indeks Prestasi (IP) maupun Indeks Prestasi Kumulatif (IPK) serta ketepatan dalam menyelesaikan studi. Dalam perkuliahan mahasiswa dituntut untuk berkompetisi dalam memperoleh prestasi akademik, yang dalam hal ini sebagai tolak ukurnya adalah indeks prestasi. Selanjutnya menurut Sugiyanto (2009: 20) bahwa salah satu keberhasilan siswa dalam pendidikan ditunjukkan dengan prestasi akademiknya. Pada kenyataannya ditemukan tuntutan prestasi akademik pada siswa semakin tinggi sementara daya belajarnya biasabiasa saja. Hal inilah yang menyebabkan tingkat keberhasilan siswa dalam prestasi akademik kurang sebagaimana diharapkan oleh sekolah, orang tua dan siswa itu sendiri 
DOI: https://doi.org/10.24127/ajpm.v8i1.1469

Masing-masing mahasiswa memiliki banyak perbedaan. Salah satu perbedaan tersebut menyangkut kapasitas intelektual yang ditunjukkan pada hasil belajar mahasiswa yang terepresentasi dalam nilai Ujian Nasional (UN). Perbedaan ini cenderung akan mengakibatkan adanya perbedaan pula dalam studi setiap mahasiswa baik dalam kecepatan studi maupun perolehan prestasi akademik (IPK). Hal ini dapat dikaitkan dengan kemampuan awal mahasiswa yang telah diperoleh pada saat di tingkat sekolah Menengah. Osuafor dan Njoku (2016) menjelaskan bahwa pengetahuan awal dapat mempengaruhi prestasi akademik mahasiswa. Lebih lanjut menurut Kurnia (2011: 98), terkait dengan keberhasilan akademik mahasiswa, banyak faktor yang mempengaruhi tingkat keberhasilan tersebut. Faktorfaktor tersebut antara lain faktor dari dalam dan luar diri mahahasiswa (faktor internal dan faktor eksternal).

Adapun faktor-faktor yang mempengaruhi prestasi akademik, Menurut Sobur (2013) terdapat beberapa faktor yang mempengaruhi prestasi akademik yaitu Pertama: faktor endogen (faktor yang berasal dari dalam individu, meliputi 1) fisik : faktor kesehatan dan anak yang mengalami kebutuhan khusus; dan 2) psikis : intelegensi, minat, bakat, motivasi, kematangan, dan kepribadian. Kedua: faktor eksogen (faktor yang berasal dari luar individu atau faktor lingkungan) meliputi: 1) keluarga: kondisi ekonomi keluarga, hubungan emosional keluarga dan anak, dan cara mendidik anak; 2) faktor sekolah : guru dan kualitas hubungan antara guru dan murid; 3) faktor lingkungan lain : kondisi keluarga, guru, dan fasilitas sekolah.

Pada penelitian yang dilakukan Anggresta (2015) terdapat delapan faktor yang memperngaruhi prestasi belajar, diantaranya: kualitas pengajaran, kemandirian belajar, variabel lingkungan keluarga, etos kerja, konsentrasi belajar, pola makan dan keinginan berhasil, penunjang belajar, serta pola asuh. Muliani, Sumardi, dan Munir (2015) menjelaskan bahwa motivasi, komitmen, dan budaya lingkungan belajar mempengaruhi prestasi belajar.

Basri

(2012:

mengemukakan bahwa Keberhasilan peserta didik termasuk mahasiswa dalam meraih prestasi belajarnya tidak lepas dari faktor - faktor yang mempengaruhinya, baik faktor yang berasal dari dalam diri individu maupun faktor yang berasal dari luar diri individu

Selanjutnya menurut Sari dan Amelia (2010) Mahasiswa yang memiliki konsep diri positif akan mampu mengembangkan kemampuan kognitif, afektif dan psikomotornya sehingga dapat mencapai prestasi akademik yang memuaskan. Hal ini tidak terlepas dari kemampuan mereka untuk menyesuaikan diri dengan lingkungan pembelajaran yang menuntut mereka untuk dapat mengembangkan softskills melalui proses pembelajaran, sehingga dapat terbentuk konsep diri yang positif.

Berdasarkan uraian latar belakang, penelitian ini dilakukan bertujuan untuk menggali dan menganalisis faktor-faktor yang mempengaruhi keberhasilan akademik mahasiswa Program Studi Pendidikan Matematika Universitas Muhammadiyah Metro, menguji signifikansi parameter model secara keseluruhan maupun secara individu, dan membentuk model logistik biner keberhasilan mahasiswa, sehingga bermanfaat untuk pertimbangan kebijakan Universitas Muhammadiyah Metro. 
DOI: https://doi.org/10.24127/ajpm.v8i1.1469

\section{METODE PENELITIAN}

Penelitian ini menggunakan metode penelitian deskriptif kualitatif, bertujuan untuk mendeskripsikan, mencatat, menganalisis dan menginterpretasikan fenomena yang diteliti. Observasi, wawancara dan dokumentasi dilakukan untuk mengumpulkan data sebanyakbanyaknya tentang variabel-variabel yang diteliti. Penelitian ini dilaksanakan untuk mendapatkan deskripsi tentang faktor-faktor yang mempengaruhi keberhasilan akademik mahasiswa Program Studi Pendidikan Matematika Universitas Muhammadiyah Metro, dan bagaimana asosiasi antara faktor-faktor yang signifikan mempengaruhi keberhasilan akademik mahasiswa.

Subyek penelitian ini adalah mahasiswa Pendidikan Matematika universitas Muhammadiyah Metro.
Sedangkan sampel yang digunakan yaitu mahasiswa Pendidikan Matematika semester 2-6 Universitas Muhammadiyah Metro Tahun Akademik 2017/2018 sebanyak 108 mahasiswa. Data yang diperoleh dianalisa dengan cara mengorganisasikan (mengumpulkan sesuai kategori) catatan lapangan hasil observasi, wawancara dan dokumentasi. Adapun keberhasilan akademik mahasiswa diukur dari Indeks Prestasi Kumulatif (IPK) sebagai peubah respon. Adapun peubah respon dikelompokan menjadi dua bagian yaitu mahasiswa yang memperoleh IPK $\leq 3,50(\mathrm{y}=0)$ dan mahasiswa yang memperoleh IPK $\geq$ $3,50(\mathrm{y}=1)$

Adapun peubah penjelas dan kategori disajikan dalam Tabel 1 berikut:

Tabel 1. Peubah penjelas dan kategori

\begin{tabular}{|c|c|c|}
\hline \multicolumn{2}{|l|}{ Peubah Penjelas } & Kategori \\
\hline \multirow[t]{2}{*}{ Jenis Kelamin } & 1. Laki-laki & \\
\hline & 2. Perempuan & \\
\hline \multirow[t]{3}{*}{ Agama } & 1. Islam & 4. Hindu \\
\hline & 2. Kristen & 5. Budha \\
\hline & 3. Katolik & 6. Khong $\mathrm{Hu} \mathrm{Cu}$ \\
\hline \multirow[t]{2}{*}{ Asal Sekolah } & 1. SMA & 3. SMK \\
\hline & 2. MA & \\
\hline \multirow[t]{2}{*}{ Jurusan } & 1. IPA & 3. Bahasa \\
\hline & 2. IPS & 4. Lainnya ....... \\
\hline Rata-Rata Nilai & 1. Nilai $\leq 55,00$ kurang & 3. $70,00>$ Nilai $\leq 85,00$ baik \\
\hline $\begin{array}{l}\text { NasionalPermendikbud no } 5 \\
\text { tahun } 2015\end{array}$ & 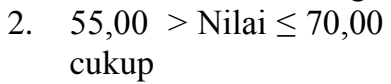 & 4. Nilai $>85,00$ Sangat Baik \\
\hline \multirow[t]{4}{*}{ Pendidikan Terakhir Ayah } & 1. Tidak Sekolah & 5. $\mathrm{S} 1$ \\
\hline & 2. SD & 6. $\mathrm{S} 2$ \\
\hline & 3. SMP & 7. $\mathrm{S} 3$ \\
\hline & 4. SMA & \\
\hline \multirow[t]{4}{*}{ Pendidikan Terakhir Ibu } & 1. Tidak Sekolah & 5. $\mathrm{S} 1$ \\
\hline & 2. SD & 6. $\mathrm{S} 2$ \\
\hline & 3. SMP & 7. $\mathrm{S} 3$ \\
\hline & 4. SMA & \\
\hline \multirow[t]{5}{*}{ Pekerjaan Ayah } & 1. PNS & 6. Wirausaha \\
\hline & 2. TNI/Polri & 7. Petani \\
\hline & 3. Pensiunan & 8. Nelayan \\
\hline & 4. Pegawai Swasta & 9. Buruh \\
\hline & 5. Wartawan & 10. Lainnya ... \\
\hline Pekerjaan Ibu & 1. PNS & 6. Wirausaha \\
\hline
\end{tabular}


DOI: https://doi.org/10.24127/ajpm.v8i1.1469

\begin{tabular}{|c|c|c|}
\hline & $\begin{array}{ll}\text { 2. } & \text { TNI/Polri } \\
\text { 3. } & \text { Pensiunan } \\
\text { 4. } & \text { Pegawai Swasta } \\
\text { 5. } & \text { Wartawan }\end{array}$ & $\begin{array}{ll}\text { 7. } & \text { Petani } \\
\text { 8. } & \text { Nelayan } \\
\text { 9. } & \text { Buruh } \\
\text { 10. } & \text {........... }\end{array}$ \\
\hline Penghasilan (P) Orangtua & 1. $\mathrm{P} \leq \mathrm{Rp} 1.000 .000,00$ & 3. $\mathrm{Rp} 3.000 .000,00>\mathrm{P} \leq \mathrm{Rp}$ \\
\hline $\begin{array}{l}\text { Perbulan (Ayah dan Ibu, } \\
\text { termasuk penghasilan } \\
\text { tambahan lainnya) }\end{array}$ & 2. $\begin{array}{l}\operatorname{Rp} 1.000 .000,00>\mathrm{P} \\
\leq \operatorname{Rp} 3.000 .000,00\end{array}$ & $\begin{array}{ll} & 5.000 .000,00 \\
\text { 4. } & \mathrm{P}>\mathrm{Rp} 5.000 .000,00\end{array}$ \\
\hline $\begin{array}{l}\text { Status Tempat Tinggal Anda } \\
\text { saat ini }\end{array}$ & $\begin{array}{ll}\text { 1. Kos/Kontrak Sendiri } \\
\text { 2. Kos/Kontrak Bersama } \\
\text { Keluarga }\end{array}$ & 3. Rumah Bersama Keluarga \\
\hline Fasilitas Laptop & $\begin{array}{l}\text { 1. Tidak Punya } \\
\text { 2. Punya }\end{array}$ & \\
\hline $\begin{array}{l}\text { Jarak ke Kampus dari } \\
\text { Tempat Tinggal }\end{array}$ & $\begin{array}{l}\text { 1. } \leq 1 \mathrm{~km} \\
\text { 2. }>1 \mathrm{~km}\end{array}$ & \\
\hline
\end{tabular}

Faktor penjelas dan peubah respon berskala kategori sehingga analisis data dilakukan dengan cara menggunakan uji metode regresi logistik dan model uji loglinear. Prosedur penelitian dan analisis data diuraikan sebagai berikut:

1. Mengumpulkan data hasil penelitian

2. Pengujian signifikansi model secara keseluruhan menggunakan uji rasio likelihood. Pengujian ini dilakukan dengan cara memodelkan semua variabel peubah yang signifikan bertujuan untuk mengetahui apakah variabel peubah berpengaruh nyata atau tidak.

3. Selanjutnya, menentukan model awal regresi logistik biner dari faktor-faktor yang mempengaruhi keberhasilan akademik mahasiswa

4. Pengujian signifikansi masingmasing parameter dalam model dengan uji wald, pengujian ini bertujuan untuk mengetahui peranan masing-masing variabel peubah.

5. Model akhir regresi logistik biner, dari faktor-faktor yang mempengaruhi keberhasilan akademik

\section{HASIL PENELITIAN DAN PEMBAHASAN}

Terlebih dahulu dilakukan seleksi dengan cara regresi logistik sederhana menggunakan program SPSS. Peubah Independen secara satu persatu dimasukkan untuk melihat nilai signifikansi ( $p$ value) terhadap peubah dependen (IPK mahasiswa). Ketentuannya yaitu jika $p$ value $<0,25$ maka peubah tersebut dapat menjadi kandidat untuk masuk ke dalam model. Untuk melakukan analisis data dengan SPSS, karena peubah yang digunakan merupakan data nominal dan ordinal dan memiliki kategori maka perlu dilakukan transformasi untuk dibuat ke dalam variabel dummy seperti tampak pada Tabel 2. 
AKSIOMA: Jurnal Program Studi Pendidikan Matematika

DOI: https://doi.org/10.24127/ajpm.v8i1.1469

Tabel 2. Peubah dalam Bentuk Dummy

\begin{tabular}{|c|c|c|c|c|c|c|c|c|}
\hline No & Peubah & Kategori & 1 & 2 & 3 & 4 & 5 & 6 \\
\hline & \multirow{2}{*}{ Jenis Kelamin } & 1. Laki-Laki & 0 & \multirow{2}{*}{-} & \multirow[b]{2}{*}{-} & \multirow[b]{2}{*}{-} & \multirow[b]{2}{*}{ - } & \multirow[b]{2}{*}{-} \\
\hline & & 2. Perempuan & 1 & & & & & \\
\hline & \multirow[t]{2}{*}{ Agama } & 1. Islam & 0 & \multirow{2}{*}{-} & \multirow{2}{*}{-} & \multirow{2}{*}{-} & \multirow{2}{*}{-} & \multirow{2}{*}{-} \\
\hline & & 2. Non Islam & 1 & & & & & \\
\hline & \multirow[t]{3}{*}{ Asal Sekolah } & 1. SMA & 0 & 0 & & & & \\
\hline & & 2. MA & 1 & 0 & - & - & - & - \\
\hline & & 3. SMK & 0 & 1 & & & & \\
\hline & \multirow[t]{3}{*}{ Jurusan } & 1. IPA & 0 & 0 & & & & \\
\hline & & 2. IPS & 1 & 0 & - & - & - & - \\
\hline & & 3. Lainnya & 0 & 1 & & & & \\
\hline & \multirow[t]{3}{*}{ Rata-Rata UN } & 1. $\leq 55,00$ & 0 & 0 & & & & \\
\hline & & 2. $55,01-70,00$ & 1 & 0 & - & - & - & - \\
\hline & & 3. $70,01-85,00$ & 0 & 1 & & & & \\
\hline & Pendidikan & 1. Tidak Sekolah & 0 & 0 & 0 & 0 & & \\
\hline & \multirow{4}{*}{ Ayah } & 2. SD & 1 & 0 & 0 & 0 & & \\
\hline & & 3. SMP & 0 & 1 & 0 & 0 & - & - \\
\hline & & 4. SMA & 0 & 0 & 1 & 0 & & \\
\hline & & 5. PT & 0 & 0 & 0 & 1 & & \\
\hline & \multirow[t]{5}{*}{ Pendidikan Ibu } & 1. Tidak Sekolah & 0 & 0 & 0 & 0 & & \\
\hline & & 2. SD & 1 & 0 & 0 & 0 & & \\
\hline & & 3. SMP & 0 & 1 & 0 & 0 & - & - \\
\hline & & 4. SMA & 0 & 0 & 1 & 0 & & \\
\hline & & 5. PT & 0 & 0 & 0 & 1 & & \\
\hline & Pekerjaan Ayah & 1. PNS & 0 & 0 & 0 & 0 & 0 & 0 \\
\hline & & 2. Pensiunan & 1 & 0 & 0 & 0 & 0 & 0 \\
\hline & & 3. Pegawai Swasta & 0 & 1 & 0 & 0 & 0 & 0 \\
\hline & & 4. Wirausaha & 0 & 0 & 1 & 0 & 0 & 0 \\
\hline & & 5. Petani & 0 & 0 & 0 & 1 & 0 & 0 \\
\hline & & 6. Buruh & 0 & 0 & 0 & 0 & 1 & 0 \\
\hline & & 7. Lainnya & 0 & 0 & 0 & 0 & 0 & 1 \\
\hline & Pekerjaan Ibu & 1. PNS & 0 & 0 & 0 & 0 & 0 & 0 \\
\hline & & 2. Pensiunan & 1 & 0 & 0 & 0 & 0 & 0 \\
\hline & & 3. Pegawai Swasta & 0 & 1 & 0 & 0 & 0 & 0 \\
\hline & & 4. Wirausaha & 0 & 0 & 1 & 0 & 0 & 0 \\
\hline & & 5. Petani & 0 & 0 & 0 & 1 & 0 & 0 \\
\hline & & 6. Buruh & 0 & 0 & 0 & 0 & 1 & 0 \\
\hline & & 7. Lainnya & 0 & 0 & 0 & 0 & 0 & 1 \\
\hline & Penghasilan & 1. $<2$ Juta & 0 & 0 & & & & \\
\hline 0 & Orangtua & 2. 2 Juta -4 Juta & 1 & 0 & - & - & - & - \\
\hline & & 3. $>4$ Juta & 0 & 1 & & & & \\
\hline & StatusTempat & 1. Kos/Kontrak Sendiri & 0 & 0 & & & & \\
\hline 1 & Tinggal & $\begin{array}{l}\text { 2. Kos/Kontrak dengan } \\
\text { Keluarga }\end{array}$ & 1 & 0 & - & - & - & - \\
\hline & & 3. Rumah dengan Keluarga & 0 & 1 & & & & \\
\hline & Fasilitas Laptop & 1. Tidak Punya & 0 & & & & & \\
\hline 2 & & 2. Punya & 1 & - & - & - & - & - \\
\hline & Asal Daerah & 1. Metro & 0 & 0 & 0 & & & \\
\hline 3 & & 2. Lampung Timur & 1 & 0 & 0 & & & \\
\hline & & 3. Lampung Tengah & 0 & 1 & 0 & - & - & - \\
\hline & & 4. Lainnya & 0 & 0 & 1 & & & \\
\hline & Jarak & 1. $\leq 5 \mathrm{~km}$ & 0 & & & & & \\
\hline 4 & Kampus & 2. $>5 \mathrm{~km}$ & 1 & - & - & - & - & - \\
\hline & Alasan & 1. Kemauan Sendiri & 0 & 0 & & & & \\
\hline 5 & Prodi & 2. Kemauan Orangtua & 1 & 0 & - & - & - & - \\
\hline & & 3. Alasan Lainnya & 0 & 1 & & & & \\
\hline
\end{tabular}


Jika peubah memiliki $n$ kategori maka terdapat $n-1$ peubah dummy yang dibuat. Sebagai contoh peubah alasan pilih prodi yang memiliki 3 kategori, maka peubah dummy yang dibuat terdapat 2 kategori yaitu $\mathrm{D}_{1}$ dan $\mathrm{D}_{2}$. Selanjutnya peubah-peubah tersebut dianalisis secara satu persatu untuk dilakukan seleksi.Rangkuman hasil seleksi bivariat terdapat pada Tabel 3 .

Tabel 3. Rangkuman Hasil Seleksi Peubah

\begin{tabular}{|c|c|c|c|}
\hline No & Peubah & Pvalue & Keterangan \\
\hline 1 & Jenis Kelamin & 0,157 & Kandidat \\
\hline 2 & Agama & 0,892 & Bukan Kandidat \\
\hline \multirow[t]{3}{*}{3} & Asal Sekolah & & \\
\hline & Asal Sekolah (1) & 0,967 & Bukan Kandidat \\
\hline & Asal Sekolah (2) & 0,777 & Bukan Kandidat \\
\hline \multirow[t]{3}{*}{4} & Jurusan & & \\
\hline & Jurusan (1) & 0,002 & Kandidat \\
\hline & Jurusan (2) & 0,777 & Bukan Kandidat \\
\hline \multirow[t]{3}{*}{5} & Rata-Rata UN & & \\
\hline & Rata-Rata UN (1) & 0,66 & Bukan Kandidat \\
\hline & Rata-Rata UN (2) & 0,418 & Bukan Kandidat \\
\hline \multirow[t]{5}{*}{6} & Pendidikan Ayah & & \\
\hline & Pendidikan Ayah (1) & 0,465 & Bukan Kandidat \\
\hline & Pendidikan Ayah (2) & 0,07 & Kandidat \\
\hline & Pendidikan Ayah (3) & 0,149 & Kandidat \\
\hline & Pendidikan Ayah (4) & 0,48 & Bukan Kandidat \\
\hline \multirow[t]{5}{*}{7} & Pendidikan Ibu & & \\
\hline & Pendidikan Ibu (1) & 0,157 & Kandidat \\
\hline & Pendidikan Ibu (2) & 0,418 & Bukan Kandidat \\
\hline & Pendidikan Ibu (3) & 0,82 & Bukan Kandidat \\
\hline & Pendidikan Ibu (4) & 0,418 & Bukan Kandidat \\
\hline \multirow[t]{7}{*}{8} & Pekerjaan Ayah & & \\
\hline & Pekerjaan Ayah (1) & 0,591 & Bukan Kandidat \\
\hline & Pekerjaan Ayah (2) & 0,625 & Bukan Kandidat \\
\hline & Pekerjaan Ayah (3) & 0,596 & Bukan Kandidat \\
\hline & Pekerjaan Ayah (4) & 0,49 & Bukan Kandidat \\
\hline & Pekerjaan Ayah (5) & 0,003 & Kandidat \\
\hline & Pekerjaan Ayah (6) & 0,335 & Bukan Kandidat \\
\hline \multirow[t]{7}{*}{9} & Pekerjaan Ibu & & \\
\hline & Pekerjaan Ibu (1) & - & Bukan Kandidat \\
\hline & Pekerjaan Ibu (2) & 0,591 & Bukan Kandidat \\
\hline & Pekerjaan Ibu (3) & 0,206 & Kandidat \\
\hline & Pekerjaan Ibu (4) & 0,815 & Bukan Kandidat \\
\hline & Pekerjaan Ibu (5) & 0,093 & Kandidat \\
\hline & Pekerjaan Ibu (6) & 0,347 & Bukan Kandidat \\
\hline \multirow[t]{3}{*}{10} & Penghasilan Orangtua & & \\
\hline & Penghasilan Orangtua (1) & 0,706 & Bukan Kandidat \\
\hline & Penghasilan Orangtua (2) & 0,264 & Bukan Kandidat \\
\hline \multirow[t]{3}{*}{11} & StatusTempat Tinggal & & \\
\hline & Status Tempat Tinggal (1) & 0,052 & Kandidat \\
\hline & Status Tempat Tinggal (2) & 0,112 & Kandidat \\
\hline 12 & Fasilitas Laptop & 0,196 & Kandidat \\
\hline \multirow[t]{4}{*}{13} & Asal Daerah & & \\
\hline & Asal Daerah (1) & 0,888 & Bukan Kandidat \\
\hline & Asal Daerah (2) & 0,942 & Bukan Kandidat \\
\hline & Asal Daerah (3) & 0,173 & Kandidat \\
\hline 14 & Jarak ke Kampus & 0,115 & Kandidat \\
\hline
\end{tabular}


DOI: https://doi.org/10.24127/ajpm.v8i1.1469

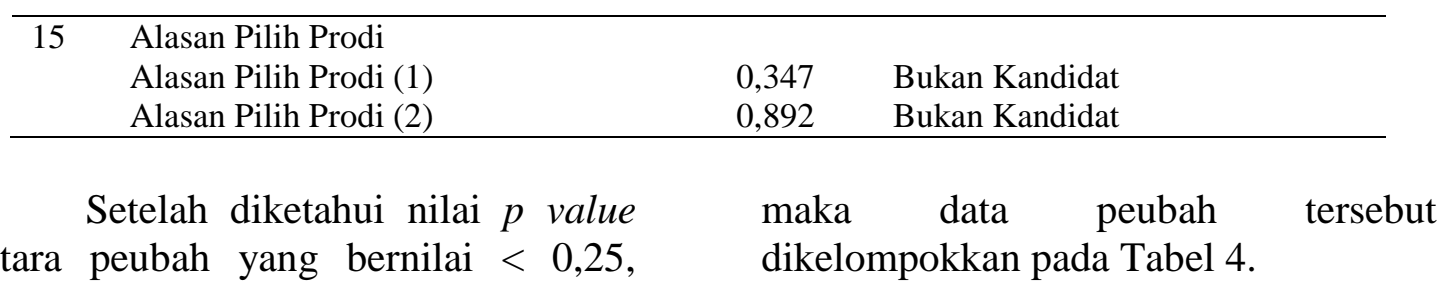

Tabel 4. Peubah yang Masuk Kandidat

\begin{tabular}{llc}
\hline \multirow{2}{*}{ No } & \multicolumn{1}{c}{ Peubah } & P value \\
& \multicolumn{1}{c}{ Jenis Kelamin } & 0,157 \\
2 & Jurusan (1) & 0,002 \\
3 & Pend. Ayah (2) & 0,07 \\
& Pend. Ayah (3) & 0,149 \\
4 & Pend. Ibu (1) & 0,147 \\
5 & Pekerjaan Ayah (5) & 0,003 \\
6 & Pekerjaan Ibu (3) & 0,206 \\
& Pekerjaan Ibu (5) & 0,093 \\
7 & Status Tempat Tinggal (1) & 0,052 \\
& Status Tempat Tinggal (2) & 0,112 \\
8 & Fasilitas Laptop & 0,196 \\
9 & Asal Daerah (3) & 0,173 \\
10 & Jarak ke Kampus & 0,115 \\
\hline
\end{tabular}

Selanjutnya dilakukan regresi logistik ganda terhadap peubah peubah tersebut. Data yang diperoleh dari uji regresi logistik ganda pada Tabel 5.

Tabel 5. Omnibus Tests of Model Coefficients

\begin{tabular}{llrrr}
\hline & & Chi-square & df & Sig. \\
\hline Step 1 & Step & 32,516 & 13 & 0,002 \\
& Block & 32,516 & 13 & 0,002 \\
& Model & 32,516 & 13 & 0,002 \\
\hline
\end{tabular}

Hipotesis:

$\mathrm{H}_{0}$ : Peubah independen secara bersama-sama tidak berpengaruh terhadap peubah dependen

$\mathrm{H}_{1}$ : Peubah independen secara bersama-sama berpengaruh terhadap peubah dependen
Dari Tabel 5 Omnibus Tests of Model Coefficients terlihat bahwa nilai signifikansi $=0.002<$ alpha (0.05) yang berarti bahwa $\mathrm{H}_{0}$ ditolak, sehingga dapat disimpulkan bahwa peubah independen secara bersama-sama berpengaruh terhadap peubah dependen.

Tabel 6. Iteration History

\begin{tabular}{lrrr}
\hline & \multicolumn{2}{c}{ Log } & \multicolumn{1}{c}{ Coefficients } \\
\cline { 3 - 3 } Iteration & & \multicolumn{1}{c}{ likelihood } & \multicolumn{1}{c}{ Constant } \\
\hline Step 0 & 1 & 142,381 & $-0,519$ \\
& 2 & 142,377 & $-0,531$ \\
& 3 & 142,377 & $-0,531$ \\
\hline
\end{tabular}

b. Initial -2 Log Likelihood: 142,377 
DOI: https://doi.org/10.24127/ajpm.v8i1.1469

Tabel 7. Model Summary

\begin{tabular}{ccrr}
\hline tep & $\begin{array}{c}-2 \text { Log } \\
\text { likelihood }\end{array}$ & $\begin{array}{c}\text { Cox \& } \\
\text { Snell R Square }\end{array}$ & $\begin{array}{c}\text { Nagelke } \\
\text { rke R Square }\end{array}$ \\
\hline & $109,861^{\mathrm{a}}$ & 0,260 & 0,355 \\
\hline
\end{tabular}

Dari Tabel 6 dan 7 terlihat penurunan -2 Log Likelihood dari 142.377 (Tabel 6 Iteration History) menjadi 109,861 (Tabel 7 Model Summary), dan berdasarkan koefisien

Tabel 8. Hosmer and Lemeshow Test

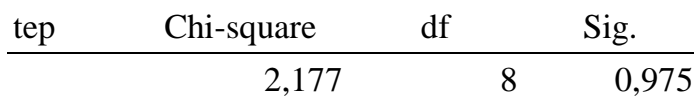

Uji Hipotesis:

$\mathrm{H}_{0}$ : Model Fit (Model mampu menjelaskan data empiris)

$\mathrm{H}_{1}$ : Model Tidak Fit

Pada Tabel 8 Hosmer and

Lemeshow Test terlihat bahwa nilai sig.

Tabel 9. Classification Table

\begin{tabular}{|c|c|c|c|c|c|}
\hline & & & \multicolumn{3}{|c|}{ Predicted } \\
\hline & & & \multicolumn{2}{|c|}{ IPK } & \multirow[b]{2}{*}{$\begin{array}{c}\text { Percentage } \\
\text { Correct }\end{array}$} \\
\hline & \multicolumn{2}{|c|}{ Observed } & $\begin{array}{c}\text { Predikat Sangat } \\
\text { Memuaskan }\end{array}$ & $\begin{array}{c}\text { Predikat } \\
\text { dengan Pujian }\end{array}$ & \\
\hline \multirow[t]{3}{*}{ Step 0} & IPK & $\begin{array}{l}\text { Predikat } \\
\text { Memuaskan }\end{array}$ & 68 & 0 & 100,0 \\
\hline & & Predikat dengan Pujian & 40 & 0 & 0,0 \\
\hline & Over & Percentage & & & 63,0 \\
\hline
\end{tabular}

$=0.975>$ alpha $(0.05)$ yang menunjukkan bahwa $\mathrm{H}_{0}$ diterima yang berarti bahwa model fit dengan data.
Nagelkerke $\mathrm{R}$ square diperoleh bahwa peubah yang dimasukkan mampu menjelaskan $35.5 \%$ keragaman total dari logit.

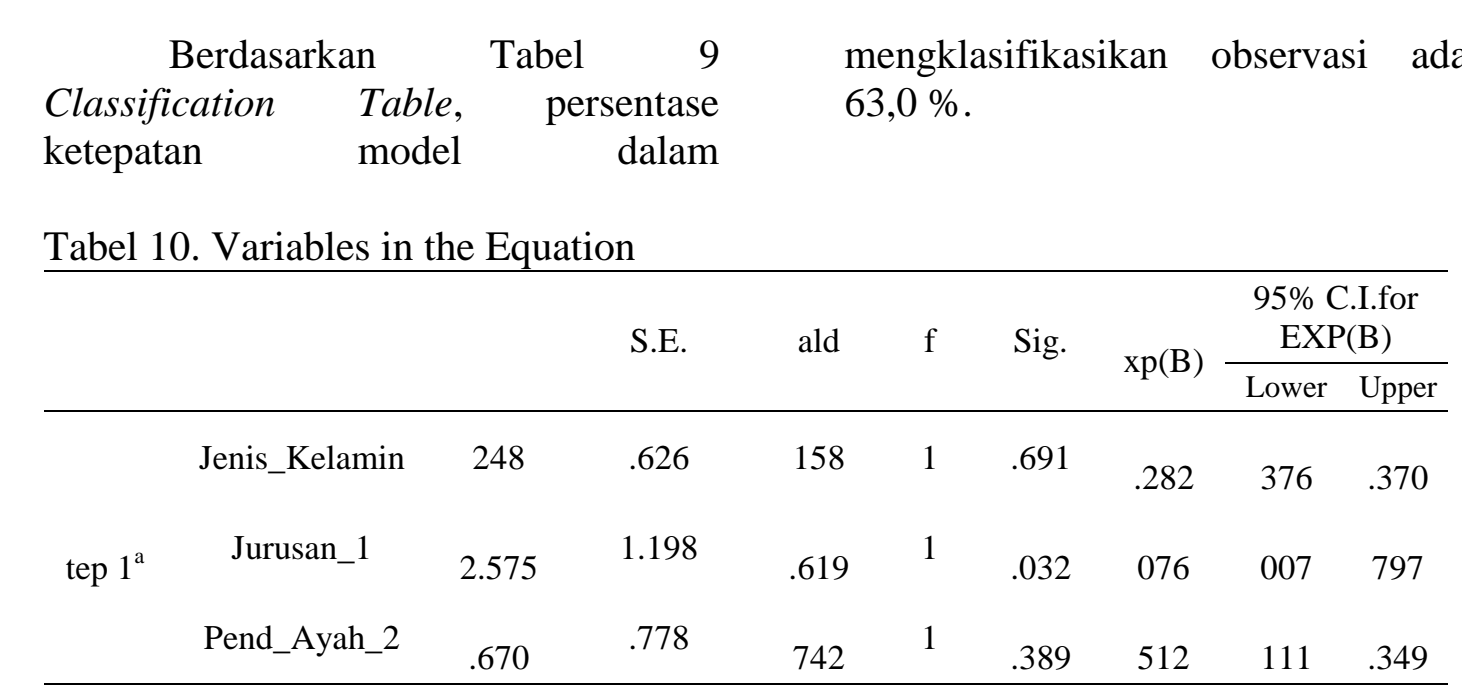


DOI: https://doi.org/10.24127/ajpm.v8i1.1469

\begin{tabular}{ccccccccc}
\hline Pend_Ayah_3 & 338 & .556 & 369 & 1 & .543 & .402 & 472 & .169 \\
Pend_Ibu_1 & .712 & .648 & .207 & 1 & .272 & 491 & 138 & .747 \\
Kerja_Ayah_5 & 19.665 & 11558.895 & 000 & 1 & .999 & 000 & 000 &. \\
Kerja_Ibu_3 & .037 & .686 & 003 & 1 & .957 & 964 & 251 & .698 \\
Kerja_Ibu_5 & 19.271 & 18789.005 & 000 & 1 & .999 & 000 & 000 &. \\
TT_1 & 20.443 & 17504.820 & 000 & 1 & .999 & 000 & 000 &. \\
TT_2 & .513 & .666 & 592 & 1 & .442 & 599 & 162 & .210 \\
Fasilitas_Laptop & 887 & .775 & .307 & 1 & .253 & .427 & 531 & 1.097 \\
Daerah_3 & 882 & .620 & .027 & 1 & 155 & .416 & 717 & .141 \\
Jarak_ke_Kampus & .417 & .645 & 417 & 1 & 518 & 659 & 186 & .334 \\
Constant & .924 & .966 & 914 & 1 & 339 & 397 & & \\
\hline
\end{tabular}

Berdasarkan Tabel 10 Variables in the Equation menunjukkan nilai sig. $<0,05$ adalah peubah jurusan, sehingga peubah yang paling berpengaruh signifikan adalah Jurusan_1 atau Jurusan IPS. Model yang terbentuk adalah

$\mathrm{g}(\mathrm{x})=-0,924-2,575$ (Jurusan_1)

Besarnya pengaruh ditunjukkan dengan nilai EXP (B) atau disebut juga ODDS RATIO (OR). Peubah jurusan_1 dengan OR 0,076 maka mahasiswa yang berasal dari jurusan IPS memiliki peluang sebanyak 0,076 kali lipat di bandingkan mahasiswa dari jurusan IPA untuk memperoleh keberhasilan akademik atau untuk memperoleh IPK dalam kategori "Dengan Pujian". Nilai $\mathrm{B}=$ Logaritma Natural dari 0,076 = 2,575. Oleh karena nilai $B$ bernilai negatif, jurusan IPS mempunyai hubungan negatif dengan keberhasilan akademik mahasiswa pendidikan matematika UM Metro.

Terdapat bagian yang sesuai dengan hasil penelitian Kurnia (2011) di mana salah satu faktor yang mendukung keberhasilan akademik mahasiswa adalah jurusan asal mahasiswa tersebut pada saat berada di tingkat sekolah menengah atas.

\section{KESIMPULAN DAN SARAN}

Berdasarkan hasil penelitian dan pembahasan, maka diperoleh kesimpulan bahwa berdasarkan peubahpeubah yang sudah dimasukkan ke dalam penelitian ini, maka faktor yang paling berpengaruh terhadap keberhasilan akademik mahasiswa yang ditunjukkan dengan perolehan IPK dengan kategori "Dengan Pujian" adalah faktor jurusan yang diambil mahasiswa pada saat menempuh pendidikan di Sekolah Menengah Atas (SMA)/sederajat. Parameter model secara keseluruhan memiliki pengaruh yang signifikan terhadap keberhasilan akademik mahasiswa dan secara individu/parsial yang berpengaruh paling signifikan adalah faktor jurusan. Model regresi yang terbentuk adalah $\mathrm{g}(\mathrm{x})=-0,924-2,575$ (Jurusan_1) 
Berdasarkan kesimpulan di atas, maka dikemukakan beberapa saran yaitu dalam menerima mahasiswa untuk program studi pendidikan matematika harus memperhatikan jurusan pada saat menempuh pendidikan di Sekolah Menengah Atas (SMA)/sederajat. Perlu ada penelitian lanjutan yang lebih mendalam untuk menggali faktor-faktor lain yang mungkin mempengaruhi keberhasilan akademik mahasiswa program studi pendidikan matematika.

\section{DAFTAR PUSTAKA}

Anggresta, V. (2015). Analisis FaktorFaktor yang Mempengaruhi Prestasi Belajar Mahasiswa Fakultas Ekonomi Universitas Negeri Padang. Economica. 4 (1), $19-29$.

Basri, S. H. (2012). Prestasi Akademik Mahasiswa Ditinjau Dari Kemampuan Literasi Media. Jurnal Dakwah, 8 (1), 15 - 38.

Daruyani, S., Wilandari, Y., dan Yasin, H. (2013). Faktor-Faktor Yang Mempengaruhi Indeks Prestasi Mahasiswa FSM Universitas Diponegoro Semaster Pertama Dengaffn Motode Regresi Logistik Biner. Prosiding Seminar Nasional Statistika Universitas Diponegoro 2013, $185-193$.

Kurnia, L. (2011). Analisis FaktorFaktor yang Mempengaruhi Keberhasilan Akademik Mahasiswa STAIN Batusangkar. Jurnal Sainstek. 3 (2), 97 - 111.

Muliani, Sumardi, dan Munir, A. R. 2015. Motivasi, Komitmen dan Budaya Lingkungan Belajar terhadap Prestasi Belajar Peserta Kursus TOEFL Preparation pada Pusat Bahasa Universitas Hasanuddin. Jurnal Analisis. 4 (2), $190-195$.
Saleh, M. (2014). Pengaruh Motivasi, Faktor Keluarga, Lingkungan Kampus dan Aktif Berorganisasi terhadap Prestasi Akademik. Jurnal Phenomenon. 4 (2), 108 141.

Sari, H dan Amelia, R. (2013). Hubungan Konsep Diri Dengan Indeks Prestasi Akademik Mahasiswa Kurikulum Berbasis Kompetensi PSIK FK Unsyiah Banda Aceh. Jurnal Ilmu Keperawatan. 1 (1), $61-75$.

Osuafor, A. M., dan Njoku, C. (2016). Effect of Prior Knowledge of Behavioural Objectives on Mathematics Achievement of High and Low Mental Ability Secondary School Students in Imo State, Nigeria. People. 2 (2), $255-264$.

Sobur, A. (2013). Psikologi Umum (dalam Lintasan Sejarah). Bandung: Pustaka Setia.

Sugiyanto. (2009). Kontribusi Motivasi Berprestasi Terhadap Prestasi Akademik Siswa Kelas XI SMA Negeri $\quad 10 \quad$ Semarang. Paradigma. 4, 19 - 34. 